\title{
Civil Society in Context of a Legal Temperament: Is the Watchdog a Capable Person?
}

\author{
SD Ndou \\ MP Sebola
}

Department of Public Administration, University of Limpopo

Email.mokoko.sebola@ul.ac.za

\section{Doi:10.5901/mjss.2014.v5n27p908}

\begin{abstract}
This paper critically analyses the concept "civil society" within a legal temperament, in an attempt to present the legal capacity of civil society organisations in their cooperation in state-society governance in South Africa. The paper argues that civil society organisations in their legal capacity as corporate person, should act as a partner in governance rather than being just a watchdog to government functions or clean administration. In its foregoing purpose the paper examines literature on the foundations of civil society and the natural law theories. The paper further explores the basis of state, market and civil society relations in good governance, where civil society is considered a legal person with capacity to act legally as a partner. The paper concludes that the legalised expression of civil society organisations legitimises the agency of human interest to the high levels of engagement and interaction as a partner in governance.
\end{abstract}

\section{Introduction}

The question of what constitute civility can be highly contested, particular at this time when there is much political mistrust in the global society, which manifests in high rate of public unrests that wave across the globe. The context under which civility should be comprehended is dependent on dynamic social and economic structures in which societies find expression of what make-up their lives. In nature civility should constitute the pursued of happiness by society at an organised collective arena, which Walzer (1990) referred to as good life, within which citizens, political community and democratic state, can be freely engaged, fully committed, as decision making members with a nation state. The pursued of happiness however include what makes people (groups and individuals) happy (Diamond, 1994) and may in some cases result unpleasant to other groups and individuals. Though common sense usually supresses logic, arguably the basic element of society is an individual natural human with own interest, therefore it could not be that the pursued of happiness (civility) comforts everyone. However tolerance, sacrifice and willingness to grow collective social, economic and governing interest, gives birth to civil society (Nweton, 2001; Ranchod, 2007). This occurs within the dense network of voluntary associations and citizens' organisations which helps to sustain civil society and community relations in a way that generates trust and cooperation between citizens and a high level of civic engagement and participation (Newton, 2001) in governance and shaping each other's future. The need to establish civil society organisations as legal persons (entities) supports a formation of a legal representative structure that promotes societal collective pursued of happiness and high level of civic engagement and participation, in particular that of governing the state and the market (Kaene, 2003). The development of civil society organisations as a legal person diminishes the view that civil society is a watchdog for governments in safeguarding democratic values of the society. However this promotes that civil society could be a critical partner in the pursued of inclusive growth and good governance of the state, particularly in a developing democracy.

Formalisation under the positivism legal theory has informed civil society to be a legal entity or person with capacity to act either legally or illegally, within its sovereign domicile (Naffine, 2003). This paper analyses and discusses the concept "civil society" within the domain of a legal temperament in an attempt to present a South African perspective of the legal capacity of civil society organisations in governing the state. The paper argues that as civil society organisations are established as corporate persons with legal capacity to act either legally or illegally, they act as partners in governance rather than being just watchdogs (Ossewaarde, 2004). This is to legitimise its role in inclusive governance and developing a better future shaped by the common interests of the public. In its foregoing purpose the paper examines literature on the foundations of civil society and the natural law theories. The paper further explores the basis of state, market and civil society relations in good governance relations, where civil society organisations are considered legal 
persons with capacity to act under juries. The paper concludes that the legalised expression of civil society organisations legitimises the agency of human interest to the high levels of engagement and interaction as a partner in governance. In its contestation the paper marches sentences drawing from four main themes namely: The foundations of civil society, the legal temperament of civil society, from watchdog to partner in governance and lastly; state, market and civil society governance relations.

\section{Natural Law Theory}

Theorising and theory plays an important role in the evolution and practice of science. Formation of theories are based on statements of knowledge that is developed by humanity, which is applicable in practice, where human act based on knowledge learned, partly from theory, and in the theoretical space where researchers validate or refute old knowledge and build new knowledge in a form of theories (Venable, 2006; Tavallaei \& Abutalib, 2010). Clear and succinct statements of theory are substance to the knowledge validation works of science. The importance of theory cannot be avoided in both natural and social science (Parsons, 1938; Levine \& Moreland, 1994). The match of the discussion, places its interpretation of the formation of civil society organisations within the natural law theory, with much emphasis on the positive law in interpreting the civil society organisation as legal persons.

The natural law theory is formed basically of two majors, which are independent of each other. Firstly the theory provides for morality as a major. Morality is basically concerned about what the society regards as naturally right and wrong. Secondly the natural law theory is concerned about the theory of positive law. Positivism law theory is about the sovereign legal status of actions, thus it is about what is legal and illegal in a particular domicile (Shapiro, 2000). The formation of civil society is based on what the society views as right and wrong about either government policy or the market (Walzer, 1990; Habib, 2005; Petlane, 2013). Such a character promotes that the notion that civil society form part of the particulars of the natural law theory of morality. Civil society organisation are formed to express the natural good that people have in conducting their life, in particular specified aspects of their action that have an impact presently and in future. Such formation allows members of the society to develop trust, and comfort amongst each other such that they entrust each other with the best interest of their community. This is expressed in the moral values and the deployment of curatorship of their resources to a group of leaders that should at all cost reciprocally manage resources which were contributed in moral faith that the interests of the civil society organisation may be put to practice.

However formalisation under the positivism legal theory has informed civil society to be a legal entity or person with capacity to act either legally or illegally, within its sovereign domicile (Naffine, 2003). This is because when civil society organisations are organised formally articulated rules that governs the action of its members, may seem to be unpreventable in that without such a natural person with his self-interest might compromise the interests of the collective. Therefore the development of rules by members of the collective association is manmade which makes them to fall under the positive law theories. Beyond that is the development of legislation by government that promotes a juristic status to civil society groups. In the context of the positive law theory, such formalisation establishes civil society organisations to be corporate persons.

\section{The Foundations of Civil Society}

At a rising moment of political shift which marked a period when the African National Congress (ANC), celebration of its century of existence finding expression of a liberated collective future of South Africa's nation state, the role of civil society is important. The South African politico society and civil society has shown off rising political animosities and mistrust, which comes to express a political desire for greater civility in social relations (Khilnani, 2001). NUMSA's decision to divorce the tripartite alliance and demand president Jacob Zuma's resignation, (which seems impossible) has also signalled a shift in the politico formations of the country. Towards the $6^{\text {th }}$ National Elections after the democratisation event of South Africa in 1994, changes may be expected in the 2014 voting polls, though might not be significant, though at a glance of complex social thinking expectations should be made beyond expectations of predictions (Thrift, 1999; Massen \& Weingart, 2000; Urry, 2003; Bogg \& Geyer, 2007) but with an understanding that the society as a complex structure with many actors, whose actions is derived from their interactions may result to an unexpected pattern. Several new political parties were launched, forming part of the list of competing parties in the 2014 elections. Amongst all a pure communist (Economic Freedom Fighters) party was formed by the influential, expelled ANCYL president Julius Malema, which has shown significant embracing into the young minds of South Africans (Ndlangisa, 2013), though using the complexity thinking, such may not be ascertained (Mackenzie, 2002), as it was unpredictable in 2007 to 2012, that president Zuma will opt for a second term, as well as that he will be most opposed and criticised by his strong 
supertasters such as Malema, Vavi, and Mathew Phosa (just to mention a few). The departing point of this paper is to provide foundational context of civil society, to locate the nature and context of South African civil society which is at the pic of chaotic state in the current moment. This is done in the pursued to present the civility or non-civilities of civil society and political society in South Africa in a legal provided space of order.

Disillusion with given boundaries of politics and with margins of dilapidated courses of party politics has triggered awareness in civil society as a means of invigorating public life (Khilnani, 2001). Civil society is argued to be as old as man and its nature it sketching back to the works of Romans and ancient Greek philosophers (Hobbes as sited in Crain \& Stavachtis, 2009) however in conventional usage civil society was discovered paralleled with the state. The contemporary ideal of civil society emerged in the Scottish and central insight of the $18^{\text {th }}$ century (Carothers, 2000). These centuries of the concepts land mark, has with some slight differences, maintained a collective view that civil society does not involve the state nor the market (Pye, 1999; Ossewaarde, 2004). A host of views during this period rose to describe the term civil society. Prominent of this host is a political view host group that viewed civil society as a domain parallel, and separate to the state and the market. In this view citizenry associate according to their own interests and wishes (Sardamov, 2005) in that people associate themselves with groups or people where they can create benefits to themselves a group dependency. Philosophers such as Aristotle, Hobbes, Gramsci and Locke, employed the term to distinguish between the state institutions (legislature, judiciary and executive) and social groups. Expressing such a distinction includes separating civil society from government departments, state agencies, parastatals and other organs of the state, with an understanding that it is a formation that challenges and cooperate with the state. However the domination of the use of civil society as a challenger or contestant (Rose \& Miller, 1992; ) or limiting state power (Fleming, 2000; ) and has made the cooperative nature of civil society to be a slumbering feature in the collective social organisation aimed at producing common good. There is a need to revive the cooperative forces of civil society of engaging productively with the state towards common good in governance, and in pursuit of delivering a good life for the society. Yet with no intention for predictions, however succumbing to the complex nature of society and operation of the state as a large and complex organisation (Senge, 1990; Stacey, 1996; Cilliers, 1998; Stacy, Griffin \& Shaw, 2000; Cilliers, 2002; Senge, 2006 Nkuna \& Sebola, 2012) may seem to be important in this discussion. It is therefore worth pointing out that to understand civil society one may require to understand the space where civil society exists and its agents as they form a complex network in which actions of such agents changes the opportunity of its predictability.

\subsection{Defining civil society}

Though civil society is being recognised in the view that it embraced social organisation at a non-state and non-market arena, it remains in the recent flurrying intellectual activity around the concept across a variety of disciplinary and ideological domains. The concept has withstand the changes of thinking and maintained its appearance, it is defined and used as valuable in deferent ways across scholarship and practice (Heins, 2004; Lewis, 2004; Sardamov, 2005; Burawoy, 2005; Mbaye, 2006). In common literature an attempt to define civil society has shown valuable attributes to the thinking of the concept. Gellner, (1996) provides one simple yet useful definition of civil society. Civil society find its expression as "that set of diverse non-governmental institutions which is strong enough to counterbalance the state and while not preventing the state from fulfilling its role of keeper of peace and arbitrator between major interests, can nevertheless prevent it from dominating and atomising the rest of the society" (Gillner, 1996:5). Critically a traditional view provided by Hegel and Gramsci (see Keane, 1988; Bauman, 1999; Walzer, 1993; Sparks, 1994; Hardt, 1995), characterises society as having a two-part structure constituting of civil society and the state. The state is produced by the ruling class to protect its privileges and wealth while civil society is defined as a space of both resistance to and the hegemonic manufacture of consent for the political domination by the ruling class. This view held that civil society has revolutionary potential to overcome state oppression and democratise the society (Fleming, 2000). Gramsci in his prison writing suggests that the endpoint of the capitalistic state is its reabsorption into civil society (Gramsci, 1971: 253).

Though without a single yardstick it is important to review several of attempted definition of the concept "civil society". A Marxist view is provided in Jaysawal (2013) which holds that civil society as not only embodying commercial institutions but also classes, corporations related with social, religious, professional life, welfare agencies, educational and training institutes concerned with civic purpose. Connelly \& Hayward (2012:41) suggest that civil society is an arena in which modern man legitimately gratifies his self-inters and develops his individuality, but also learns the value of group action, social solidarity and the dependence of his welfare on others. This view promotes that civil societies are not made to change man self-profiting nature but to allow man to grow individual, and learning to value group action while informing social solidarity as in dynamic societies ones welfare is dependent of the actions of the others. Halloway (2001:13) describes civil society as citizens, associating neither for power nor profit, are the third sector of society, complementing 
government and business and they are the people who constitute civil society organisations. Thus incorporators of civil society has no interest in gaining profit or power, in that though representation may be the representatives (executive or leaders) will allow members of the society to govern the actions of the civil society organisation, and theirs will be to represent the view of the whole body of the civil society. In this paper civil society is viewed as society's formation beyond market forces and state-centric institutions. It is a formation that strengthens the public sphere and provides a haven for intense production of public common good through interaction. In Ndou, (2013: 189) and Ljubownikow, Crotty and Rodgers (2013: 153-166) a consideration of civil society is recognised with the view that it is a place where overlapping networks of autonomous voluntary associations, formally and informally, politically and non-politically, create the space for public collective action between individuals and the state. This definition informs that civil society involves a complex structure that has a variety of actors, whose actions contributed to actions of the state and the market (Stacey, 1996). Variation of actions by the state, the market and civil society may through the glance of complex thinking result in a chaotic state where at equilibrium of integration by the social actors results may establish a new order or collapse.

\section{The Legal Temperament of Civil Society in South Africa}

The South African legal system is composed of a mix of legal traditions as a result of colonisation. As South Africa was colonised by both the Dutch and the English so is the law influencing the justice system and legal operations in the country (Naffine, 2003). The civil legal tradition was principally influenced by the Dutch, while on the other hand the common law developed from the English tradition. This combination of legal systems is a result of South Africa's colonisation by both the English and the Dutch. It is also worth noting that indigenous law remains a significant part of the South African legal system (Wyngaard, 2010). The South African constitutional law dispensation has further resulted in the development of common, through the invalidation of statutory laws which are found to be inconsistent the Constitution of South Africa, 1996. South Africa is a three sphere (usually referred as spheres of government) decentralised government. There are deferent provisions of national, provincial and local laws (South Africa, 1996). The powers of each tire of government are set out by the constitution. Supplementary to the constitution is an array of national, provincial and local sphere developed legislation that is used in the execution and administration of the country's operations. Laws dealing with civil society in South African are enacted at the national sphere of government. The national government regulates the establishment, registration and taxation of civil society organisations. The legal formation of civil society is discussed in this part of the paper, with therefore aim to provide the context of civil society as a legal person in South Africa.

\subsection{Legal personality framework of Civil Society}

Because legal systems differ from each domicile to another it is important to determine which legal system can be used to establish civil society as a legal persona in South Africa. In accordance with such a legal system, it must be determined whether and to what extent the civil society has a legal capacity to act, litigate or to be held accountable, for crime or delict. The concern in this argument is to determine the ability of the civil society to have rights and duties; to perform valid juristic acts (such as entering into a contract); and be a party to a law suit in being a partner in the South African governance. The determination of the legal system can be established by identifying the domicile of such civil society organisations within the legal space (thus either national, provincial, or local) of South African governance system. Formation of civil society in South Africa takes point from an array of legislation such as the companies Act of 2008, the Property Control Act of 1988, and the Non-Profit Organisations Act 1997. To determine the legal temperament of civil society is as important as its formation. If civil society has a legal identity with capacity to act under jurisdiction, the author is of the view that it is accorded a status to act juristically in playing its democratic roles in the society. Positive commitment, of civil society under the positive law should hold that the existence of legal systems and legal rules are ultimately determined by certain facts about the socials of domicile they serve (Shapiro, 2000). Such socials are established in legal citizen boundaries under national frameworks. The following legal provisions in South Africa (as a domicile) can be used to reflect the legal temperament of civil society.

\subsubsection{The Constitution of the Republic of South Africa, 1996}

The Constitution of the Republic of South African of 1996 as a supreme law of the country provides in the bill of rights the individual freedoms to be exercised in the land. Yet though the constitution confers such individual rights such rights are used in acting within South Africa legally or illegally. Section 15 of the Constitution of the Republic of South Africa, 1996, 
provides for freedom of religion, belief and opinion. These activities are prominent practices in the civil society. Civil society found its expression under particular social beliefs and opinions that constitute a common good of the society. Religious and belief-based civil society are seen in the definition provided by the London School of Economics Centre for Civil Society, which states that "civil society is the arena of uncoerced collective action around shared interest, purpose and values. In theory, its institutional forms are distinct from those of the state, family and market, though in practice, the boundaries between state, civil society, family and market are often complex, blurred and negotiated. Civil society commonly embraces a diversity of spaces, actors and institutional forms, varying in their degree of formality, autonomy and purpose (Ranchod, 2007; Deibert, Palfrey, Rohozinski, \& Zuttrain, 2008: 124). The definition sufficiently puts that civil society contains values of believers, and embrace opinions of individuals into group values and productivity. This also assists individuals by promoting social learning of individuals and development of a social identity. Section 16(1) of the Constitution further extends freedom of expression, which is a critical element of civil society in particular of its relation to the state. It values the ability of the individual or collective expression of opinions on matters affecting their social and economy environment. This constitutional section also bears a gross impact on media, public awareness, creativity and innovation, as well as the freedom for the education based civil society to conduct research and academic activity. This is provided with limitation in section 16(2) that such freedom may not lead to propaganda of war incitement of imminent violence or advocacy of hatred that is based on race, ethnicity, gender or religion and that constitutes incitement to causes harm, of which are strong basis for civil society. Section 17, 18 and 19 of the Constitution further deals with the freedom of individuals to form part of collective action, in a just and peaceful manner, this element justifies the non-violent nature of civil society in its engagement with the state. For the formation of civil society as a legal person the following legislation are discussed.

\subsubsection{Companies Act, 2008}

By definition the Companies Act, of 2008 provides that a company is a juristic person incorporated in terms of the act. Two types of companies may be formed and incorporated under the act, namely a profit and a non-profit company of which the discussion in this paper is concerned with the later. A non-profit company is a company incorporated in terms of the act, for a public benefit or other object as required in terms of item 1(1) of schedule one of the act. Incomes and property are not distributable to its incorporators, members, directors, officers or persons related to it subject to item 1(3) of schedule one in the act. The act therefore gives basis for civil society organisation registered in terms of the act and the NPOA, 1988 to have sufficient capacity to act as a legal person within its jurisdiction. The founders of civil society Organisations are given a formal relationship with the organisation (which is a juristic person). The act in section 2(1) states that an individual is related to another, (in this case it will refer to a natural person who incorporated a civil society organisation and the organisation as a juristic person) if (section 2(1) b) an individual is related to a juristic person, if the individual directly or indirectly controls the juristic person. Further juristic (non-natural) persons are given formal relationship; in that (section 2(1) c) a juristic person is related to another of either of them directly or indirectly controls the other. There are two or more entities that have a relationship with a civil society organisation as a legal person that of the state established in terms of the constitution, since the state has a capacity to act legally or illegally in its name it is regarded as a legal person. Private companies as well as the capacity of a person created in terms of the companies act, 2008 (see also section 3). The legal status therefore of companies is provided for in section 19(1), in that from the date and time that the incorporation of a company is registered, as stated in its registration certificate, the company is a juristic person, which exists continuously until its name is removed from the companies register in accordance with the provisions of the act. A registered non-profit organisation which forms part of the population of civil society is conferred with legal powers and capacity of an individual. It is within the premises of the provision of this act that a juristic person can be recognised in civil society organisations and thus provide a basis for its relation with the state and the market to be based on mutual partnership and capability to hold one another legally liable for acting in compromise of the interest of such a relationship.

\subsubsection{Trust Property Control Act, 1988}

A trust exist when the creators (founders) of the trust, hands or bound to hand over to another party legally referred to as trustees, the control of property including money which is to be administered for the benefit of some person or for some impersonal objects or purpose (). In the development of such and account, a document namely a "trust deed" is established to set out; the objects of the trust, appointment of trustees and powers of such trustees, the use of such trust assets. A valid discretionary trust is created when its objects are lawful and sufficiently certain. Such certainty is achieved 
when beneficiaries or classes of beneficiaries under the trust are specified with sufficient clarity. The Trust act, 1988 requires Trustees to act with care, diligence and skill which can reasonably be expected of a person who manages the affairs of another. It is thus important that trustees avoid self-serving decisions and partiality. The relative relations to common usage of the term civil society with provisions of this act is that civil society entrust its property to a wide range of trustees. It is also agreed that civil society consents the curatorship of the public's money to government official to deal with the daily transactions of the state.

\subsubsection{Non-Profit Organisation Act, 1997.}

The Non-Profit Organisation Act, 1997 (NPOA) came into operation on 1 September 1998. The NPOA was established with objects to create an environment in which non-profit organisations can flourish. The act serves as an administrative and regulatory framework for non-profit organisation to conduct their affairs. It further encourages NPOs to maintain adequate standards of governance, transparency, and accountability as well as improving public access to information concerning registered NPOs. Chapter two of the NPOA provides for the development of Directorate for NPOs and appointment of a Director. Responsibilities of the directorate include preparation and issue of model constitutions and codes of good practice for the NPOs. Registration of NPOs is provided for in chapter three of the act. Section 12(1) of the Non-Profit Organisations Act states that the registration of NPOs in South Africa is conducted voluntarily. According to the act a NPO refers to "a trust, company or other association of persons established for a public purpose, and the income and property of which are not distributable to its members or office bearers expected as reasonable compensation for service rendered". The definition provides therefore that NPOs covers for three forms of entities, that of a discretionary trust, a section 21 company and a voluntary association, qualifying as NPOs (Nyapotse Inc, n.d). Section 16(1) of the act asserts that the issue of a certificate of registration for an NPO as provided for in section 15(1) is sufficient proof that the organisation is a body corporate. Therefore to the doubt if whether a voluntary association is corporate or juristic person, its registration as a NPO will confirm that the organisation is a body separate in law from its members, precisely that the principle of limited liability applies. This is the basis that forms NPOs which are part of civil society as legal person with the ability to be held liable or sued in its name.

\section{From Watchdog to Partner in Governance}

Jaysawal (2013) describe a report by the former United Nations Secretary General Kofi Anan (2002 as sited in Jayswal, 2013), the report focus on strengthening the UN, with the purpose of further change in the UN's agenda. The report stresses that a multiplicity of actors, namely civil society and the private sector are increasingly involved in international cooperation. Though such argument place a notion that the key distinction with civil society is the idea of activism that tackles international problems and act across geographical borders, and generally interrelated with the process of enhancing globalisation and turbo-capitalism (Tubbush, 2005). The report puts it clear that civil society is an arena in which modern man do not only legitimately gratifies his self-interest and develops his individuality, but learns the value of groups' actions, social solidarity, and the dependence of his welfare on others, which educate him for citizenship and prepare him for participation in the political arena of state (Walzer, 1993). In the millennium declaration, civil society is considered a partner to overcome the goals set by the developmental agenda. At a broader socio-political representation by a trained group of civil individual who work in the public and political society to increase the indent of public interest in the works of the state. This representative should be understood to be accountable to the civil society which is also accountable to the beneficiaries of civil society organisations own work and formations.

\section{State, Market and Civil Society Governance Relations}

The authors contend that there is renewed interest in civil society, since the fall and disintegration of radical forces in the political space of South Africa. Though civil society is a central focus in the debate to find solutions in governance of the state and the economy, it is also advanced that civil society should be strong for promoting democracy, growing the economy and solving social problem (Fleming, 2000). Civil society is interested in critiquing how the state and the economy operate (Rose \& Miller, 1999). This therefore forms the basis of the relations between the state, the market and civil society. Given the variety of views about civil society, Gramsci provides with a very useful view, to understand civil society, when emphasising on the symbolic dimension of civil society's role in the formation of values, actions-oriented norms, meanings, and identifications. This view promotes that civil society does not only transmit or inculcate established practise or beliefs, it is also a site for social contestation, in which collective identities, ethical values, and alliances are 
forged. This therefore gives birth to a collective order of conducting the state by the communities.

The confirmation of civil society as a space to reshape the state conduct can be seen in the partnership of the state with civil society in policy formations. Civil society asserts itself as a bulwark against the systematising effects of the state and the market. Thus in civil society people discusses matters of mutual concern as peers, and learn about facts, events and the opinions, interests and perspectives of others in an atmosphere free of coercion or inequality which may incline individuals to acquiesce or be silent (Habermas, 1996). In this space of discussion and discourse on values, norms, laws and policies allows politically relevant public opinion, which could be used for ordering government and the market. In the purpose of this paper the view above is sufficient to locate civil society as a sphere of interaction between the market and state, composed of intimate relations, associations, social movements and public communications in efforts of bringing a common good (Cohen \& Arato, 1992; Cunningham, 1992).

\section{Conclusion}

The frequency of debated about what constitute a mane of law by jurists, can be discussed based on moral and legal point of view. However in the twenty first century, societies have come into terms with the legal status and legal personification of corporation, such as civil society organisations. It however a complex concept in the context of criminal law to establish organisational entities as persons, since such contestation will required the establishing a criminal mind, or independent will, for which an abstraction like an NGO may not have. The personification of entities is backed by their influence in the political and economic endeavours of the society. Civil Society Organisations are machinery for the delivery of democratic view of the society in the development and implementation of policies. This make them to form constituency to the governing bodies of countries, therefore their establishment as legal person with juristic capacity promotes their legitimacy in high level of engagement and decision making with the state and market actors.

\section{References}

Bogg, J., \& Geyer, R., 2007. The Complexity Turn. Theory, Culture and Society. Vol. 22(5): 1-14.

Carothers, C., 2000. Civil Society. Foreign Policy. Think Again. Winter 1999-2000: 18-29.

Cohen, J., \& Arato, A., 1992. Civil Society and Political Theory. MIT Press, Cambridge.

Connelly, J., \& Hayward, J., 2012. The Withering of the Welfare State-Regression. Palgrave Macmillan.

Cunningham, P., 1992. From Freire to Feminism: the North American Experience with Critical Pedagogy. Adult Education Quarterly. Vol. 42(3): 9-17.

Deibert, R., Palfrey, J., Rohozinski, R., \& Zittrian, J., 2008. Access Denied: the Practice and Policy of Global Internet Filtering. The MIT Press, Cambridge.

Diamond, L., 1994. Rethinking Civil Society: Toward Democratic Consolidation. Journal of Democracy. Vol. 5(3): 4-17.

Fleming, T., 2000. Habermas, Democracy and Civil Society: Unearthing the Social in Transformation Theory. In Wissner, C., Mayer, S., \& Fuller, D., (eds), Challenges of Practice :Learning in Action. Columbia University, New York.

Gellner, L., 1996. Conditions of Liberty: Civil Society and its Rivals. Penguin, London.

Gramsci, A., 1971. Selection from the Prison Notebooks of Antonio Gramsci. Hoare, Q., \& Smith, G.N., eds. Lawrence and Wishart, London.

Habermas, J., 1996. Between Facts and Norms: Contributions to a Discourse Theory of Law and Democracy. Polity Press, Cambridge.

Halloway, R., 2001. A Handbook on Resource Mobilisation for Civil Society Organisation in the South. Leftword, New Delhi.

Hardt, M., 1995. The Withering of Civil Society. Social Text. Vol. 45 (14)

Heins, V., 2004. Civil Society's Barbarisms. European Journal of Social Theory. Vol. 7(4): 499-517.

Jaysawal, N., 2013. Civil Society, Democratic Space, and Social Work. SAGE Open Journal. 1-12.

Keane, J., 1988. Democracy and Civil Society. Verso, London.

Maasen, S., \& Weingart, P., 2000. Metaphors and the Dynamics of Knowledge. Routledge, London.

Mackenzie, A., 2002. Transductions: Bodies and Machines at Speed. Continuum, New York.

Mahajan, G., 1999. Civil Society and its Avatars: What Happened to Freedom and Democracy. Economic and Political Weekly. Vol. 34(20): 1188-1196.

Mbaye, L., 2006. Re-conceptualising Civil Society: The Debate Continues with Specific Reference to Contemporary Senegal. African and Asian Studies. Vol. 5(1): 91-118.

Ndlangisa, S., 2013. EFF "Founded on Principle of Non-Corruption". City Press. Posted 11 July 2013. Available at : www.citypress.co.za/politics/eff-founded-on-principle-of-non-coruption-malema/ ( accessed 11-01-2014)

Ndou, S.D., 2013. The Tripartite Alliance as a Sine Qua Non in Promoting Public Interest and Accountability in the Post-Apartheid South African Governance. Journal of Public Administration. Vol. 48 (1): 188-194.

O'Connell, B., 2000. Civil Society: Definitions and Discribtions. Non-profit and Voluntary Sector Quarterly. Vol. 29: 471-478.

Ossewaarde, M.R.R., 2004. Tocqueville's Moral and Political Thought: New Liberalism. Routledge, London. 
Pye, L.W., 1999. Civility, Social Capital, ad Civil Society: Three Powerful Concepts for Explaining Asia. Journal of Interdisciplinary History. Vol. 29(4): 763-782.

Rose, N., \& Miller, P., 1992. Political Power Beyond the State: Problematics of Government. British Journal of Sociology. Vol. 43(2):

Sardamov, I., 2005. Civil Society and the Limits of Democratic Assistance. Governance and Opposition. Vol. 40(3): 379-402.

Senge, P.M., \& Sterman, J.D., 1990. Systems Thinking and Organisational Learning: Acting Locally and Thinking Globally in the Organisation of the Future. Systems Dynamics. Vol. 9(1): 1007-1022.

Shapiro, S.J., 2000. Law, Morality and Guidance of Conduct. Legal Theory. Vol.; 6(1): 127-170.

Shapiro, S.J., 2000. Law, Morality, and the Guidance of Conduct. Legal Theory. Vol. 6: 127-170.

Sparks, C., 1994. Civil Society and Information Society as Guarantors of Progress. In Splichal, A., Calabrese, A., \& Sparks, C., (eds). Information Society and Civil Society. Purdue University Press, West Lafayette.

Sterman, J.D., 1994. Learning in and About Complex Systems. System Dynamic Review. Vol. 10 (2-3): 291-330.

The Companies Act, 2008 (71 of 2008). Government Printer, Pretoria.

The Constitution of the Republic of South Africa, 1996. Government Printers, Pretoria.

The Non-Profit Organisations Act, 1997 (71 of 1997). Government Printers, Pretoria.

The Trust Property Control Act, 1988 (57 of 1988). Government Printers, Pretoria.

Thrift, N.,1999. The Place of Complexity. Theory, Culture and Society. Vol. 16(3): 31-70.

Tubbush, C., 2005. Civil society in United Nations Conferences. United Nations.

Urry, J., 2003. Global Complexity. Polity, Cambridge.

Walzer, M., 1993. Exclusion, Injustice, and the Democratic State. Dissent. Winter

Wyngaard, R.G., 2010. Sub-Saharan Africa Country Reports. International Journal of Not-for-Profit Law. Vol. 12 (2): 65-77. 